\title{
Supplements of vitamins B9 and B12 affect hepatic and mammary gland gene expression profiles in lactating dairy cows
}

\author{
Bazoumana Ouattara ${ }^{1 *}$, Nathalie Bissonnette ${ }^{1}$, Melissa Duplessis ${ }^{1,2}$ and Christiane L. Girard ${ }^{1}$
}

\begin{abstract}
Background: A combined supplement of vitamins B9 and B12 was reported to increase milk and milk component yields of dairy cows without effect on feed intake. The present study was undertaken to verify whether this supplementation positively modifies the pathways involved in milk and milk component synthesis. Thus, by studying the transcriptome activity in these tissues, the effect of supplements of both vitamins on the metabolism of both liver and mammary gland, was investigated. For this study, 24 multiparous Holstein dairy cows were assigned to 6 blocks of 4 animals each according to previous 305-day milk production. Within each block, cows were randomly assigned to weekly intramuscular injections of $5 \mathrm{~mL}$ of either saline $0.9 \% \mathrm{NaCl}, 320 \mathrm{mg}$ of vitamin B9, 10 mg of vitamin B12 or a combination of both vitamins (B9+B12). The experimental period began 3 weeks before the expected calving date and lasted 9 weeks of lactation. Liver and mammary biopsies were performed on lactating dairy cows $64 \pm 3$ days after calving. Samples from both tissues were analyzed by microarray and qPCR to identify genes differentially expressed in hepatic and mammary tissues.
\end{abstract}

Results: Microarray analysis identified 47 genes in hepatic tissue and 16 genes in the mammary gland whose expression was modified by the vitamin supplements. Gene ontology (GO) categorizes genes in non-overlapping domains of molecular biology. Panther is one of the online GO resources used for gene function classification. It classifies the 63 genes according to Molecular Function, Biological Process and Protein Class. Most of the biological processes modulated by the vitamin supplements were associated to developmental process, protein metabolic process, transport and response to inflammation. In the liver, most of the genes modulated by the vitamin treatments involved protein metabolic process while developmental process appeared to be more affected by the treatments in mammary gland. Out of 25 genes analysed by qPCR, 7 were validated.

Conclusion: The results indicate that several metabolic processes were modulated by the supplementation of vitamins in early-lactating dairy cows. In addition, the results suggest that the vitamin supplements promoted liver regeneration and reduced catabolism of lipids in early lactation.

Keywords: Dairy cow, Liver, Mammary gland, Vitamin B9, Vitamin B12, Microarray

\section{Background}

Bacteria present in rumen synthesize B vitamins in generally sufficient amounts to meet their host's requirements [1]. Notwithstanding, high-producing dairy cows could benefit from vitamin B9 and B12 supplements, especially during the critical period around calving and in early lactation [2-4]. Vitamin B9 plays a major role in

\footnotetext{
* Correspondence: bazouma.ouattara@upgc.edu.ci

${ }^{1}$ Sherbrooke Research and Development Centre, Agriculture and Agri-Food

Canada, Sherbrooke, QC J1M 0C8, Canada

Full list of author information is available at the end of the article
}

DNA synthesis and in de novo formation of methyl groups required for the methylation cycle. On the other hand, vitamin B12 is involved in two metabolic pathways: the remethylation cycle and as coenzyme of the methylmalonyl-CoA mutase. The former, closely related to folate metabolism, is required for the regeneration of methionine and tetrahydrofolate, whereas the later allows the entry of propionate in the Krebs cycle and gluconeogenesis [5].

Results from two studies suggest that supplementary vitamin B9 might improve efficiency of nutrient utilization, 
especially for milk protein synthesis $[6,7]$. This observation is supported by the observation that in vitro hormonal stimulation of milk protein synthesis by mammary gland explants of dairy cows increased expression of 28 genes; among them, 2 genes related to folate metabolism, FOLR1 and ALDH1L1 [8]. The former is a folate transporter allowing the entry of 5-methyl-tetrahydrofolate into the cells whereas the latter is involved in purine synthesis. As vitamin B9 supplement increases milk protein synthesis, it would be interesting to investigate whether similar transcriptomic process takes place in vivo when vitamin supplements are provided to lactating cows.

A combined supplement of vitamins B9 and B12 given during the peripartum period and in early lactation altered energy partitioning during the first weeks of lactation as compared to control cows $[3,4,9]$. However, the mode of action of this supplement is not fully elucidated. We observed that a combined supplement of vitamins B9 and B12 increases whole-body rate of appearance of glucose which is the sum of glucose from portal absorption, glycogenolysis, and gluconeogenesis [3]. Propionate originating from rumen fermentation is the major precursor of glucose in cows $[10,11]$ and contributes up to $60 \%$ of glucose flux rate [12, 13]. For ruminants, the glucose, essential for synthesis of milk lactose, is mostly provided by liver (up to $90 \%$ ) through gluconeogenesis [14].

It has been shown that at the onset of lactation, the liver as well as the mammary gland undergo numerous adaptations to support milk synthesis [15]. In early lactation, feed intake is not sufficient to meet the nutrient demand for milk production, leading to a negative energy balance [15]. Furthermore, the liver undergoes extensive physiological and biochemical changes mediated by significant alterations in hepatic gene expression in an attempt to re-establish metabolic homeostasis and to counteract the adverse effects of negative energy balance [16]. In addition, during this period, the mammary gland is actively remodeling. In fact, by investigating the transcriptional response of the mammary gland during early lactation, Connor et al. [17] observed changes in mammary expression of genes involved in cell proliferation, cellular remodeling, and nutrient transport.

Therefore, the aim of the present project was to profile the genes for which expression undergoes major changes in hepatic and mammary tissues of lactating dairy cows according to vitamins B9 and B12 supply.

\section{Results}

At week 9 of lactation, there was no treatment effect $(P \geq 0.1)$ on dry matter intake, milk production, milk total solid yields as well as milk component contents. Dry matter intake, milk production, milk total solid yields, milk fat, protein and lactose contents averaged 18.8 (SE 1.9) kg/d, 34.7 (SE 2.9) kg/d, 3.92 (SE 0.33) kg/d,
36.0 (SE 2.0) g/kg, 30.2 (SE 1.4) g/kg, and 46.9 (SE 6.0) $\mathrm{g} / \mathrm{kg}$, respectively. During the seven weeks following calving, body condition score losses tended to be reduced (interaction vitamin $\times$ time, $P=0.10$ ) in cows receiving the vitamin B9 supplements, alone or combined with vitamin B12. Plasma concentrations of non-esterified fatty acids and $\beta$-hydroxybutyrate were also lower $(P \leq 0.06)$, averaging 175 and $243 \mu \mathrm{M}$ (SEM 17) and 0.70 and $0.77 \mathrm{mM}$ (SEM 0.03) for cows receiving or not receiving supplementary vitamin $\mathrm{B} 9$, respectively.

The microarray analysis revealed that, as compared to control cows receiving no vitamin supplement, the vitamin treatments significantly changed (FDR $\leq 0.05$ ) the expression of some genes by more than 2-fold in hepatic and mammary tissues (Fig. $1 \mathrm{a}$ and $\mathrm{b}$, respectively). The expression of 47 genes in hepatic tissue was modified by at least one of the vitamin treatment compared to control cows (Fig. 1a). From this panel of 47 genes, 41 could be assigned to a biological process using the Panther classification system (Tables 1 and 2). Out of these 47 genes, expression of 14 genes was analyzed by qPCR (Fig. 2). Although nine false positive genes were observed, five genes were confirmed to be differentially expressed in the group of cows supplemented with vitamins.

The expression of two genes was significantly modified in liver by the B9 treatment as illustrated in the Venn diagram (Fig. 1a). One gene that also significantly downregulated by the B12 treatment was confirmed by qPCR for these cows. This repression of DLK1 in liver was down-regulated by the three vitamin treatments (Fig. 2). The B12 treatment had the greatest impact on the liver with 22 genes (totalizing 39 significant probes; Fig. 1a) whose expression level differed by more than 2 -fold compared to control (Table 2).

Among the 22 genes affected by the B12 treatment, four genes were also influenced in cows receiving the $\mathrm{B} 9+\mathrm{B} 12$ treatment: the methallothioneins $1 \mathrm{~A}(M T 1 A)$ and $1 \mathrm{E}$ (MTIE), the transmembrane glycoprotein (GPNMB), and an uncharacterized protein (MGC126945) (Table 1). Expression of two of these genes (MT1A and GPNMB) was studied by qPCR (Fig. 2). This analysis confirmed the repression of MTIA in liver of cows receiving B12 and B9 + B12 treatments. Results from the microarray analysis indicated an up-regulation of the expression of GPNMB with both $\mathrm{B} 12$ and $\mathrm{B} 9+\mathrm{B} 12$ treatments. The qPCR analysis showed a numerical but not statistically significant increase with these treatments probably due to the large variation in the expression for this gene among the limited number of animals of this study (Fig. 2). Among the other 17 genes affected by the B12 treatment, the expression of seven genes were studied by qPCR but no effect were confirmed for 6 of them (HERC6, IF127, ISG15, MEP1B, PPP1R3B and SFRP1). Only the expression of the G0/G1switch 2 gene (GOS2) 
a

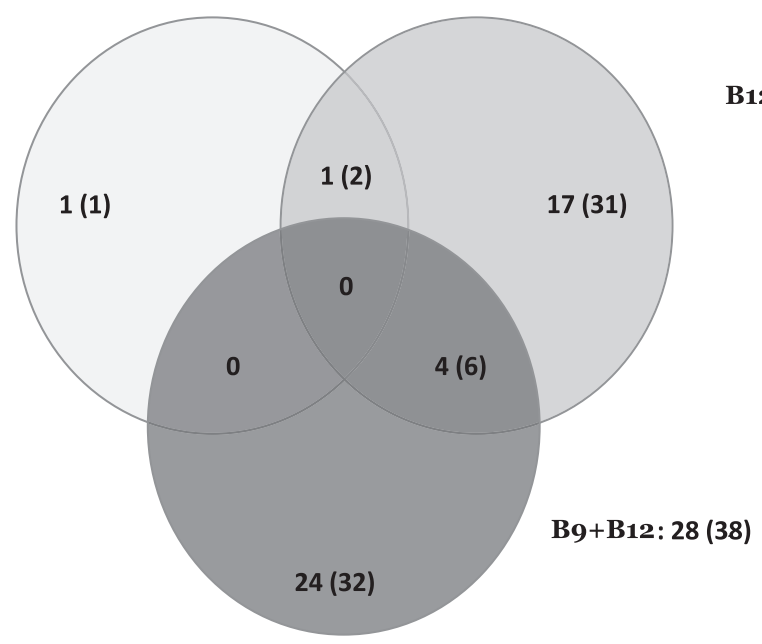

B12: 22 (39)

B9: 2 (3)

b

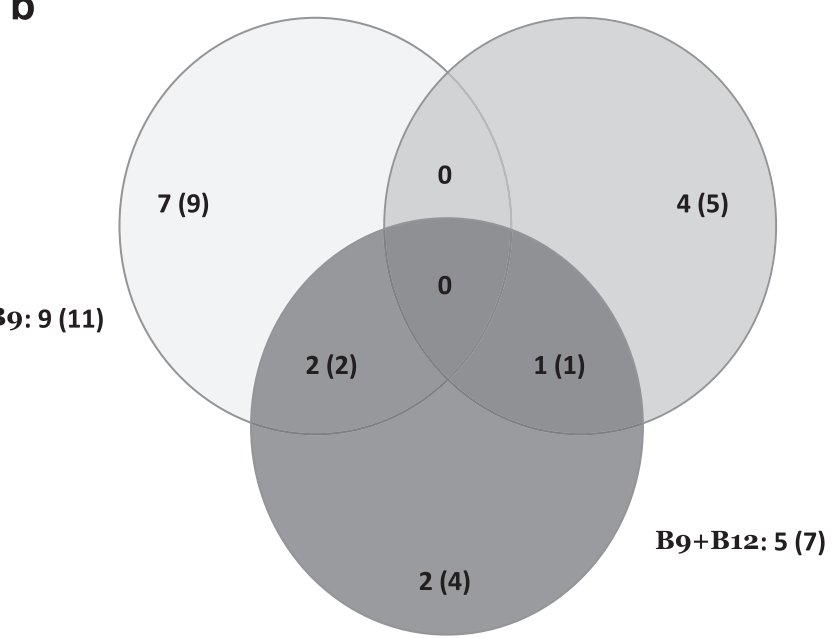

Fig. 1 Number of genes (and probes) influenced by the vitamin supplementation. Supplements of vitamin B9 (B9), vitamin B12 (B12) or both vitamins (B9 + B12) were given to dairy cows. The Venn diagram shows the number of significant genes. The number of probes is bracketed "()". (FDR $\leq 0.05)$ with more than 2-fold change between the control group and each treatment group in (a) hepatic tissue and (b) mammary tissue

was up-regulated in liver of cows receiving the B12 treatment as compared to control (Fig. 2).

In addition to these four genes influenced by B12 treatment, alone and in combination with B9, 24 other genes were affected when both vitamins were administrated simultaneously to the cows; four genes were studied by qPCR. Two of them, namely the haptoprotein $(H P)$ and lysyl oxidase-like 4 (LOXL4), were confirmed as being respectively down and up-regulated by the combined treatment. Nevertheless, the expression of LOXL4 was also up-regulated in liver of $\mathrm{B} 9$ cows whereas, the expression of $H P$ was down-regulated by all vitamin treatments (Fig. 2). No difference in expression of GSTA5 and SLC22A9 could be detected.

In mammary gland, the B9 treatment modified the expression of nine genes by 2 -fold as compared to cows receiving no vitamin supplement. The B12 treatment affected five genes and the expression of five genes was influenced by the B9+B12 treatment (Fig. 1b). The $\mathrm{B} 9+\mathrm{B} 12$ shared one gene with the B12 treatment. Based on results from the microarray analysis, three genes whose expression was modified by the B9 treatment (Fig. 1b), cell death-inducing DFFA-like effector a $(C I D E A)$, the androgen binding protein beta-like (LOC785756), and the periostin (POSTN) genes were studied by qPCR in addition to some candidate genes (Fig. 3). Out of the 11 genes analyzed by qPCR, two genes were confirmed; then, the percentage of false positive in the mammary was $82 \% . R A B 15$ and POSTN were significantly up-regulated respectively by the B12 and B9 as compared to control (Fig. 3). Out of the 16 genes affected in the mammary gland by vitamin supplements, 13 were classified using Panther classification system (Table 3 ). 
Table 1 Gene Ontology annotations of the differentially expressed hepatic genes with the Panther Classification System ${ }^{a}$

\begin{tabular}{|c|c|c|c|c|c|c|}
\hline Treatment & Gene symbol & Gene name & Treatment effect & Molecular function & Biological process & Protein class \\
\hline \multicolumn{7}{|l|}{ B9 } \\
\hline DLK1 & & Delta-like 1 homolog (Drosophila) & Down-regulated & $\begin{array}{l}\text { receptor activity } \\
\text { extracellular matrix } \\
\text { structural constituent } \\
\text { receptor binding }\end{array}$ & $\begin{array}{l}\text { transcription from RNA } \\
\text { polymerase II promoter } \\
\text { cell communication } \\
\text { ectoderm development } \\
\text { nervous system development } \\
\text { intracellular protein transport } \\
\text { receptor-mediated endocytosis } \\
\text { regulation of transcription from } \\
\text { RNA polymerase II promoter }\end{array}$ & $\begin{array}{l}\text { membrane-bound } \\
\text { signaling molecule } \\
\text { receptor } \\
\text { extracellular matrix } \\
\text { structural protein }\end{array}$ \\
\hline MYOM1 & & Myomesin-1 & Down-regulated & $\begin{array}{l}\text { protein kinase activity } \\
\text { structural constituent } \\
\text { of cytoskeleton } \\
\text { protein binding } \\
\text { small GTPase regulator activity } \\
\text { guanyl-nucleotide exchange } \\
\text { factor activity }\end{array}$ & $\begin{array}{l}\text { protein phosphorylation } \\
\text { cell communication } \\
\text { cell adhesion } \\
\text { muscle contraction } \\
\text { mesoderm development } \\
\text { muscle organ development } \\
\text { regulation of catalytic activity }\end{array}$ & $\begin{array}{l}\text { non-receptor serine/threonine } \\
\text { protein kinase } \\
\text { non-receptor serine/threonine } \\
\text { protein kinase } \\
\text { guanyl-nucleotide } \\
\text { exchange factor } \\
\text { actin family cytoskeletal protein } \\
\text { cell adhesion molecule }\end{array}$ \\
\hline \multicolumn{7}{|l|}{ B12 } \\
\hline HERC6 & & $\begin{array}{l}\text { HECT and RLD domain containing } \\
\text { E3 ubiquitin protein ligase } \\
\text { family member } 6\end{array}$ & Up-regulated & ligase activity & $\begin{array}{l}\text { catabolic process } \\
\text { cellular protein modification } \\
\text { process } \\
\text { proteolysis } \\
\text { cellular process }\end{array}$ & ubiquitin-protein ligase \\
\hline SESN2 & & Sestrin-2 & Up-regulated & $\begin{array}{l}\text { oxidoreductase activity } \\
\text { peroxidase activity }\end{array}$ & $\begin{array}{l}\text { metabolic process } \\
\text { cell cycle }\end{array}$ & Peroxidase \\
\hline GPNMB & & glycoprotein (transmembrane) nmb & Up-regulated & receptor binding & cellular process & $\begin{array}{l}\text { membrane-bound } \\
\text { signaling molecule } \\
\text { cell adhesion molecule }\end{array}$ \\
\hline$|F| 6$ & & Interferon alpha-inducible protein 6 & Up-regulated & Unassigned & Unassigned & Unassigned \\
\hline PPP1R3B & & $\begin{array}{l}\text { Protein phosphatase } 1 \\
\text { regulatory subunit } 3 \mathrm{~B}\end{array}$ & Up-regulated & $\begin{array}{l}\text { phosphatase activity } \\
\text { protein binding } \\
\text { phosphatase regulator activity }\end{array}$ & $\begin{array}{l}\text { glycogen metabolic process } \\
\text { regulation of catalytic activity }\end{array}$ & phosphatase modulator \\
\hline ID1 & & ID1 protein & Up-regulated & $\begin{array}{l}\text { sequence-specific DNA } \\
\text { binding transcription } \\
\text { factor activity }\end{array}$ & $\begin{array}{l}\text { transcription from RNA } \\
\text { polymerase II promoter } \\
\text { regulation of transcription from } \\
\text { RNA polymerase II promoter }\end{array}$ & transcription factor \\
\hline$|F| 27$ & & interferon, alpha-inducible protein 27 & Up-regulated & Unassigned & Unassigned & Unassigned \\
\hline MEP1B & & meprin A, beta & Up-regulated & $\begin{array}{l}\text { oxidoreductase activity } \\
\text { serine-type peptidase activity } \\
\text { metallopeptidase activity } \\
\text { receptor activity } \\
\text { lipid transporter activity }\end{array}$ & $\begin{array}{l}\text { immune system process } \\
\text { proteolysis } \\
\text { synaptic transmission } \\
\text { cell-cell adhesion } \\
\text { visual perception } \\
\text { sensory perception }\end{array}$ & $\begin{array}{l}\text { transporter } \\
\text { apolipoprotein } \\
\text { membrane-bound } \\
\text { signaling molecule } \\
\text { receptor } \\
\text { metalloprotease }\end{array}$ \\
\hline
\end{tabular}


Table 1 Gene Ontology annotations of the differentially expressed hepatic genes with the Panther Classification System ${ }^{\mathrm{a}}$ (Continued)

\begin{tabular}{|c|c|c|c|c|c|}
\hline & & & $\begin{array}{l}\text { transmembrane transporter } \\
\text { activity } \\
\text { receptor binding } \\
\text { enzyme regulator activity }\end{array}$ & $\begin{array}{l}\text { ectoderm development } \\
\text { mesoderm development } \\
\text { skeletal system development } \\
\text { angiogenesis } \\
\text { nervous system development } \\
\text { heart development } \\
\text { blood coagulation } \\
\text { lipid transport } \\
\text { intracellular protein transport } \\
\text { endocytosis } \\
\text { vitamin transport } \\
\text { regulation of catalytic activity }\end{array}$ & $\begin{array}{l}\text { serine protease } \\
\text { oxidase } \\
\text { metalloprotease } \\
\text { serine protease } \\
\text { extracellular matrix protein } \\
\text { enzyme modulator } \\
\text { cell adhesion molecule }\end{array}$ \\
\hline FUT5 & $\begin{array}{l}\text { fucosyltransferase } 5 \text { (alpha } \\
(1,3) \text { fucosyltransferase }\end{array}$ & Up-regulated & $\begin{array}{l}\text { transferase activity, } \\
\text { transferring glycosyl groups }\end{array}$ & protein glycosylation & glycosyltransferase \\
\hline GOS2 & G0/G1switch 2 & Up-regulated & Unassigned & Unassigned & Unassigned \\
\hline CDK5R1 & Cyclin-dependent kinase 5 activator 1 & Up-regulated & $\begin{array}{l}\text { kinase activity } \\
\text { protein binding } \\
\text { kinase activator activity } \\
\text { kinase regulator activity }\end{array}$ & $\begin{array}{l}\text { protein phosphorylation } \\
\text { cell cycle } \\
\text { regulation of catalytic activity }\end{array}$ & kinase activator \\
\hline ISG15 & Ubiquitin-like protein ISG15 & Up-regulated & $\begin{array}{l}\text { structural constituent of ribosome } \\
\text { nucleic acid binding }\end{array}$ & proteolysis & ribosomal protein \\
\hline LOC515676 & $\begin{array}{l}\text { NFX1-type zinc finger-containing } \\
\text { protein 1-like }\end{array}$ & Up-regulated & $\begin{array}{l}\text { peptidase activity } \\
\text { protein binding } \\
\text { serine-type endopeptidase } \\
\text { inhibitor activity }\end{array}$ & $\begin{array}{l}\text { proteolysis } \\
\text { regulation of catalytic activity }\end{array}$ & serine protease inhibitor \\
\hline SPP1 & Osteopontin & Up-regulated & cytokine activity & $\begin{array}{l}\text { immune system process } \\
\text { cellular process } \\
\text { cell adhesion } \\
\text { cellular component } \\
\text { morphogenesis } \\
\text { cellular component organization }\end{array}$ & $\begin{array}{l}\text { cytokine } \\
\text { extracellular matrix protein } \\
\text { defense/immunity protein } \\
\text { cell adhesion molecule }\end{array}$ \\
\hline DLK1 & Delta-like 1 homolog (Drosophila) & Down-regulated & $\begin{array}{l}\text { receptor activity } \\
\text { extracellular matrix structural } \\
\text { constituent } \\
\text { receptor binding }\end{array}$ & $\begin{array}{l}\text { transcription from RNA } \\
\text { polymerase II promoter } \\
\text { cell communication } \\
\text { ectoderm development } \\
\text { nervous system development } \\
\text { intracellular protein transport } \\
\text { receptor-mediated endocytosis } \\
\text { regulation of transcription from } \\
\text { RNA polymerase II promoter }\end{array}$ & $\begin{array}{l}\text { membrane-bound } \\
\text { signaling molecule } \\
\text { receptor } \\
\text { extracellular matrix } \\
\text { structural protein }\end{array}$ \\
\hline MYOM1 & Myomesin-1 & Down-regulated & $\begin{array}{l}\text { protein kinase activity } \\
\text { structural constituent of } \\
\text { cytoskeleton } \\
\text { protein binding } \\
\text { small GTPase regulator activity } \\
\text { guanyl-nucleotide exchange } \\
\text { factor activity }\end{array}$ & $\begin{array}{l}\text { protein phosphorylation } \\
\text { cell communication } \\
\text { cell adhesion } \\
\text { muscle contraction } \\
\text { mesoderm development } \\
\text { muscle organ development } \\
\text { regulation of catalytic activity }\end{array}$ & $\begin{array}{l}\text { non-receptor serine/threonine } \\
\text { protein kinase } \\
\text { non-receptor serine/threonine } \\
\text { protein kinase } \\
\text { guanyl-nucleotide } \\
\text { exchange factor }\end{array}$ \\
\hline
\end{tabular}


Table 1 Gene Ontology annotations of the differentially expressed hepatic genes with the Panther Classification System ${ }^{\mathrm{a}}$ (Continued)

\begin{tabular}{|c|c|c|c|c|c|}
\hline & & & & & $\begin{array}{l}\text { actin family } \\
\text { cytoskeletal protein } \\
\text { cell adhesion molecule }\end{array}$ \\
\hline MTIE & $\begin{array}{l}\text { Metallothionein } \\
\text { MT1E }\end{array}$ & Down-regulated & Unassigned & Unassigned & Unassigned \\
\hline NEFH & $\begin{array}{l}\text { ortholog } \\
\text { Uncharacterized protein } \\
\text { (Fragment) } \\
\text { NEFH } \\
\text { ortholog }\end{array}$ & Down-regulated & Unassigned & Unassigned & Unassigned \\
\hline SFRP1 & Secreted frizzled-related protein 1 & Down-regulated & $\begin{array}{l}\text { receptor activity } \\
\text { protein binding }\end{array}$ & $\begin{array}{l}\text { reproduction } \\
\text { cell communication } \\
\text { single-multicellular organism } \\
\text { process } \\
\text { nervous system development } \\
\text { response to stimulus } \\
\text { regulation of biological process }\end{array}$ & $\begin{array}{l}\text { signaling molecule } \\
\text { G-protein coupled receptor }\end{array}$ \\
\hline KIAA1324 & KIAA1324 ortholog & Down-regulated & Unassigned & Unassigned & Unassigned \\
\hline MGC126945 & Uncharacterized protein & Down-regulated & receptor activity & $\begin{array}{l}\text { B cell mediated immunity } \\
\text { antigen processing and } \\
\text { presentation } \\
\text { cellular defense response }\end{array}$ & $\begin{array}{l}\text { immunoglobulin receptor } \\
\text { superfamily } \\
\text { immunoglobulin receptor } \\
\text { superfamily } \\
\text { major histocompatibility } \\
\text { complex antigen }\end{array}$ \\
\hline MT1A & $\begin{array}{l}\text { Metallothionein-1A } \\
\text { MT1A }\end{array}$ & Down-regulated & Unassigned & Unassigned & Unassigned \\
\hline \multicolumn{6}{|l|}{$\mathrm{B} 9+\mathrm{B} 12$} \\
\hline SAA3 & Serum amyloid A protein & Down-regulated & $\begin{array}{l}\text { lipid transporter activity } \\
\text { transmembrane } \\
\text { transporter activity }\end{array}$ & $\begin{array}{l}\text { immune system process } \\
\text { lipid transport }\end{array}$ & $\begin{array}{l}\text { transporter } \\
\text { apolipoprotein } \\
\text { defense/immunity protein }\end{array}$ \\
\hline LOC100126815 & MHC class I-like family A1 & Down-regulated & receptor activity & $\begin{array}{l}\text { B cell mediated immunity } \\
\text { antigen processing and } \\
\text { presentation } \\
\text { cellular defense response }\end{array}$ & $\begin{array}{l}\text { immunoglobulin receptor } \\
\text { superfamily } \\
\text { immunoglobulin receptor } \\
\text { superfamily } \\
\text { major histocompatibility } \\
\text { complex antigen }\end{array}$ \\
\hline ACMSD & $\begin{array}{l}\text { 2-amino-3-carboxymuconate-6- } \\
\text { semialdehyde decarboxylase }\end{array}$ & Down-regulated & Unassigned & Unassigned & Unassigned \\
\hline THRSP & THRSP protein & Down-regulated & Unassigned & Unassigned & Unassigned \\
\hline MGC126945 & Uncharacterized protein & Down-regulated & receptor activity & $\begin{array}{l}\text { B cell mediated immunity } \\
\text { antigen processing and } \\
\text { presentation } \\
\text { cellular defense response }\end{array}$ & $\begin{array}{l}\text { immunoglobulin receptor } \\
\text { superfamily } \\
\text { immunoglobulin receptor } \\
\text { superfamily } \\
\text { major histocompatibility } \\
\text { complex antigen }\end{array}$ \\
\hline
\end{tabular}


Table 1 Gene Ontology annotations of the differentially expressed hepatic genes with the Panther Classification System ${ }^{\text {a }}$ (Continued)

\begin{tabular}{|c|c|c|c|c|c|}
\hline MT1A & $\begin{array}{l}\text { Metallothionein-1A } \\
\text { MT1A }\end{array}$ & Down-regulated & Unassigned & Unassigned & Unassigned \\
\hline C4H7orf57 & $\begin{array}{l}\text { chromosome } 4 \text { open reading } \\
\text { frame, human C7orf } 57\end{array}$ & Down-regulated & Unassigned & Unassigned & Unassigned \\
\hline CACNA2D1 & $\begin{array}{l}\text { calcium channel, voltage-dependent, } \\
\text { alpha } 2 / \text { delta subunit }\end{array}$ & Down-regulated & $\begin{array}{l}\text { cation transmembrane } \\
\text { transporter activity }\end{array}$ & $\begin{array}{l}\text { cation transport } \\
\text { protein targeting }\end{array}$ & Unassigned \\
\hline GSTA5 & Glutathione S-transferase & Down-regulated & Unassigned & Unassigned & Unassigned \\
\hline LOC509034 & $\begin{array}{l}\text { feline leukemia virus subgroup } \\
\mathrm{C} \text { receptor-related protein 2-like }\end{array}$ & Down-regulated & $\begin{array}{l}\text { transmembrane } \\
\text { transporter activity }\end{array}$ & transport & transporter \\
\hline NHEDC1 & $\begin{array}{l}\text { solute carrier family } 9 \text {, subfamily } \\
\text { B (cation proton antiporter } 2) \text {, } \\
\text { member } 1\end{array}$ & Down-regulated & Unassigned & Unassigned & Unassigned \\
\hline SH3YL1 & $\begin{array}{l}\text { SH3 domain-containing } \\
\text { YSC84-like protein } 1\end{array}$ & Down-regulated & $\begin{array}{l}\text { structural constituent } \\
\text { of cytoskeleton } \\
\text { actin binding }\end{array}$ & cellular process & $\begin{array}{l}\text { non-motor actin } \\
\text { binding protein }\end{array}$ \\
\hline$H P$ & Haptoglobin & Down-regulated & $\begin{array}{l}\text { serine-type peptidase activity } \\
\text { calcium ion binding } \\
\text { calmodulin binding } \\
\text { calcium-dependent } \\
\text { phospholipid binding }\end{array}$ & $\begin{array}{l}\text { gamete generation } \\
\text { complement activation } \\
\text { proteolysis } \\
\text { cellular process } \\
\text { blood circulation } \\
\text { response to stress } \\
\text { blood coagulation }\end{array}$ & $\begin{array}{l}\text { serine protease } \\
\text { serine protease } \\
\text { complement component } \\
\text { annexin } \\
\text { calmodulin }\end{array}$ \\
\hline NGEF & $\begin{array}{l}\text { neuronal guanine nucleotide } \\
\text { exchange factor }\end{array}$ & Down-regulated & Unassigned & Unassigned & Unassigned \\
\hline LGALS3 & $\begin{array}{l}\text { Lectin, galactoside-binding, } \\
\text { soluble, } 3\end{array}$ & Up-regulated & receptor binding & cellular process & $\begin{array}{l}\text { signaling molecule } \\
\text { cell adhesion molecule }\end{array}$ \\
\hline LOC524810 & $\lg M$ & Up-regulated & Unassigned & Unassigned & Unassigned \\
\hline LOXL4 & Lysyl oxidase homolog 4 & Up-regulated & $\begin{array}{l}\text { oxidoreductase activity } \\
\text { serine-type peptidase activity } \\
\text { receptor activity }\end{array}$ & $\begin{array}{l}\text { macrophage activation } \\
\text { apoptotic process } \\
\text { proteolysis } \\
\text { cell communication } \\
\text { cell-cell adhesion } \\
\text { neurological system process } \\
\text { cellular defense response } \\
\text { extracellular transport } \\
\text { negative regulation of } \\
\text { apoptotic process }\end{array}$ & $\begin{array}{l}\text { receptor } \\
\text { serine protease } \\
\text { oxidase } \\
\text { serine protease }\end{array}$ \\
\hline PYCR1 & $\begin{array}{l}\text { Pyrroline-5-carboxylate reductase } 1 \text {, } \\
\text { mitochondrial }\end{array}$ & Up-regulated & oxidoreductase activity & $\begin{array}{l}\text { cellular amino acid } \\
\text { biosynthetic process }\end{array}$ & reductase \\
\hline MSMB & Uncharacterized protein & Up-regulated & hormone activity & & peptide hormone \\
\hline IGLL1 & $\begin{array}{l}\text { immunoglobulin lambda-like } \\
\text { polypeptide } 1\end{array}$ & Up-regulated & antigen binding & $\begin{array}{l}\text { B cell mediated immunity } \\
\text { hemopoiesis } \\
\text { response to stimulus }\end{array}$ & Immunoglobulin \\
\hline
\end{tabular}


Table 1 Gene Ontology annotations of the differentially expressed hepatic genes with the Panther Classification System ${ }^{\text {a }}$ (Continued)

\begin{tabular}{|c|c|c|c|c|c|}
\hline MTIE & $\begin{array}{l}\text { Metallothionein } \\
\text { MT1E }\end{array}$ & Down-regulated & Unassigned & Unassigned & Unassigned \\
\hline GPNMB & glycoprotein (transmembrane) nmb & Up-regulated & receptor binding & cellular process & $\begin{array}{l}\text { membrane-bound } \\
\text { signaling molecule } \\
\text { cell adhesion molecule }\end{array}$ \\
\hline
\end{tabular}

All genes differentially expressed in liver were classified using the Gene Ontology annotations with the Panther Classification System. Some of these genes were not found by Panther genes list analysing system and some could not be classified. Only three ontology categories are presented: Molecular Function, Biological Process and Protein Class

a Panther gene list classification system of the genes differentially expressed in hepatic tissue of cows receiving vitamin supplements (vitamin B9 alone: B9, vitamin B12 alone: B12 or both vitamins: B9 + B12) as compared to no vitamins treatment (Control) 
Table 2 Identification of the major biological processes of the genes differentially expressed in hepatic tissue

\begin{tabular}{|c|c|c|c|}
\hline \multicolumn{2}{|l|}{ Biological process } & \multicolumn{2}{|l|}{ Genes } \\
\hline Level 1 & Level 2/3 & Symbol & Fold Change \\
\hline apoptotic process & negative regulation of apoptotic process & LOXL4 & 1.6 \\
\hline biological adhesion & cell adhesion & $\begin{array}{l}\text { MYOM1 } \\
\text { SPP1 } \\
\text { MEP1B } \\
\text { LOXL4 }\end{array}$ & $\begin{array}{l}-2.5 \\
0.9 \\
1.3 \\
1.6\end{array}$ \\
\hline \multirow[t]{2}{*}{ biological regulation } & regulation of biological process & $\begin{array}{l}\text { DLK1 } \\
\text { SFRP1 } \\
\text { ID1 } \\
\text { LOXL4 }\end{array}$ & $\begin{array}{l}-2.5 \\
-1.8 \\
1.1 \\
1.6\end{array}$ \\
\hline & regulation of molecular function & $\begin{array}{l}\text { MYOM1 } \\
\text { CDK5R1 } \\
\text { PPP1R3B } \\
\text { MEP1B } \\
\text { LOC515676 }\end{array}$ & $\begin{array}{l}-2.5 \\
0.8 \\
1.1 \\
1.3 \\
1.9\end{array}$ \\
\hline $\begin{array}{l}\text { cellular component organization } \\
\text { or biogenesis }\end{array}$ & cellular component organization & SPP1 & 0.9 \\
\hline \multirow[t]{2}{*}{ cellular process } & cell communication & $\begin{array}{l}\text { DLK1 } \\
\text { MYOM1 } \\
\text { SFRP1 } \\
\text { MEP1B } \\
\text { LOXL4 }\end{array}$ & $\begin{array}{l}-2.5 \\
-2.5 \\
-1.8 \\
1.3 \\
1.6\end{array}$ \\
\hline & cell cycle & $\begin{array}{l}\text { CDK5R1 } \\
\text { SESN2 }\end{array}$ & $\begin{array}{l}0.8 \\
0.9\end{array}$ \\
\hline \multirow[t]{5}{*}{ developmental process } & anatomical structure morphogenesis & SPP1 & 0.9 \\
\hline & death & LOXL4 & 1.6 \\
\hline & ectoderm development & $\begin{array}{l}\text { DLK1 } \\
\text { MEP1B }\end{array}$ & $\begin{array}{l}-2.5 \\
1.3\end{array}$ \\
\hline & mesoderm development & $\begin{array}{l}\text { MYOM1 } \\
\text { MEP1B }\end{array}$ & $\begin{array}{l}-2.5 \\
1.3\end{array}$ \\
\hline & system development & $\begin{array}{l}\text { DLK1 } \\
\text { MYOM1 } \\
\text { SFRP1 } \\
\text { MEP1B } \\
\text { IGLL1 }\end{array}$ & $\begin{array}{l}-2.5 \\
-2.5 \\
-1.8 \\
1.3 \\
2.1\end{array}$ \\
\hline \multirow[t]{3}{*}{ immune system process } & antigen processing and presentation & $\begin{array}{l}\text { LOC100126815 } \\
\text { MGC126945 }\end{array}$ & $\begin{array}{l}-2.4 \\
-1.8\end{array}$ \\
\hline & immune response & $\begin{array}{l}\text { LOC100126815 } \\
\text { MGC126945 } \\
\text { HP } \\
\text { IGLL1 }\end{array}$ & $\begin{array}{l}-2.4 \\
-1.8 \\
-1.6 \\
2.1\end{array}$ \\
\hline & macrophage activation & LOXL4 & 1.6 \\
\hline localization & transport & $\begin{array}{l}\text { DLK1 } \\
\text { LOC509034 } \\
\text { SAA3 } \\
\text { CACNA2D1 } \\
\text { MEP1B } \\
\text { LOXL4 }\end{array}$ & $\begin{array}{l}-2.5 \\
-1.5 \\
-1.1 \\
-1.0 \\
1.3 \\
1.6\end{array}$ \\
\hline \multirow[t]{5}{*}{ metabolic process } & catabolic process & HERC6 & 1.8 \\
\hline & carbohydrate metabolic process & PPP1R3B & 1.1 \\
\hline & cellular amino acid metabolic process & PYCR1 & 1.5 \\
\hline & nucleobase-containing compound metabolic process & $\begin{array}{l}D L K 1 \\
I D 1\end{array}$ & $\begin{array}{l}-2.5 \\
1.1\end{array}$ \\
\hline & protein metabolic process & $\begin{array}{l}\text { MYOM1 } \\
\text { HP } \\
\text { CDK5R1 } \\
\text { MEP1B }\end{array}$ & $\begin{array}{l}-2.5 \\
-1.6 \\
0.8 \\
1.3\end{array}$ \\
\hline
\end{tabular}


Table 2 Identification of the major biological processes of the genes differentially expressed in hepatic tissue ${ }^{\text {a }}$ (Continued)

\begin{tabular}{|c|c|c|c|}
\hline & & $\begin{array}{l}\text { LOXL4 } \\
\text { FUT5 } \\
\text { HERC6 } \\
\text { LOC515676 } \\
\text { ISG15 }\end{array}$ & $\begin{array}{l}1.6 \\
1.6 \\
1.8 \\
1.9 \\
2.5\end{array}$ \\
\hline multicellular organismal process & single-multicellular organism process & $\begin{array}{l}\text { MYOM1 } \\
\text { SFRP1 } \\
\text { HP } \\
\text { MEP1B } \\
\text { LOXL4 }\end{array}$ & $\begin{array}{l}-2.5 \\
-1.8 \\
-1.6 \\
1.3 \\
1.6\end{array}$ \\
\hline reproduction & gamete generation & $H P$ & -1.6 \\
\hline \multirow[t]{4}{*}{ response to stimulus } & cellular defense response & $\begin{array}{l}\text { LOC100126815 } \\
\text { MGC126945 } \\
\text { LOXL4 }\end{array}$ & $\begin{array}{l}-2.4 \\
-1.8 \\
1.6\end{array}$ \\
\hline & 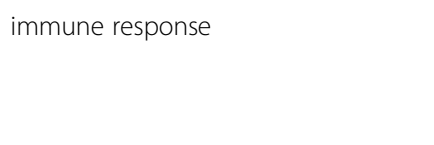 & $\begin{array}{l}\text { LOC100126815 } \\
\text { MGC126945 } \\
\text { HP } \\
\text { IGLL1 }\end{array}$ & $\begin{array}{l}-2.4 \\
-1.8 \\
-1.6 \\
2.1\end{array}$ \\
\hline & response to external stimulus & $\begin{array}{l}\text { HP } \\
\text { MEP1B }\end{array}$ & $\begin{array}{l}-1.6 \\
1.3\end{array}$ \\
\hline & response to stress & $H P$ & -1.6 \\
\hline Not found & & $\begin{array}{l}\text { C20H5orf49 LOC789904 } \\
\text { SLC22A9 } \\
\text { CFH } \\
\text { SLC26A10 } \\
\text { SAA2 } \\
\text { M-SAA3 } \\
\text { LOC100847494 } \\
\text { LOC100335975 } \\
\text { LOC617654 }\end{array}$ & $\begin{array}{l}-1.9 \\
-1.8 \\
-1.7 \\
-1.5 \\
-1.4 \\
-1.2 \\
-1.1 \\
-0.9 \\
1.4 \\
4.2\end{array}$ \\
\hline Unassigned & & $\begin{array}{l}\text { C4H7orf57 } \\
\text { MT1E } \\
\text { MT1A } \\
\text { THRSP } \\
\text { KIAA1324 } \\
\text { NGEF } \\
\text { GSTA5 } \\
\text { ACMSD } \\
\text { NHEDC1 } \\
\text { NEFH } \\
\text { GOS2 } \\
\text { LOC524810 } \\
\text { IFI27 } \\
\text { IFI6 }\end{array}$ & $\begin{array}{l}-4.4 \\
-3.4 \\
-3.3 \\
-1.7 \\
-1.6 \\
-1.4 \\
-1.3 \\
-1.2 \\
-1.1 \\
-1.1 \\
1.9 \\
2.6 \\
3.3 \\
3.7\end{array}$ \\
\hline
\end{tabular}

All genes modulated in the liver by the vitamins treatment, including those that were not found or classified by the Panther system are listed. The fold change observed by microarray analysis varies from -4.4 to 4.2 and only significantly (FDR $\leq 0.05$ ) expressed genes (compared to control) are shown

adentification of the major biological processes of the genes differentially expressed in hepatic tissue of cows receiving vitamin supplements (vitamin B9 alone: B9, vitamin B12 alone: B12 or both vitamins: B9 + B12) as compared to no vitamins treatment (Control)

As shown in Tables 1 and 3, some of the genes identified by microarray in liver and mammary gland were annotated and clustered into three major gene ontology groups: Protein Class, Molecular Function and Biological Process. In Tables 2 and 4, gene expression clusters are categorized within biological processes (levels 1, 2 and 3). This allows looking for statistically over- and under-represented biological process categories among the genes. Most of the genes modulated in the liver by at least one of the vitamin supplements were associated to developmental process, protein metabolic process, transport and immune response
(Table 2). However, protein metabolic process was overrepresented (with 9 genes: MYOM1, HP, CDK5R1, MEP1B, LOXL4, FUT5, HERC6, LOC515676 and ISG15) in the gene list affected by treatments in the liver (Table 2). In the mammary gland, where very few genes were affected by the vitamin treatments, the over-represented biological process was developmental process involving 4 genes: CIDEA, POSTN, GPR110 and IRX6 (Table 4).

Gene symbols were uploaded to the Panther workspace in order to classify the genes of interest by selecting the Bos taurus reference gene list based on the selected 


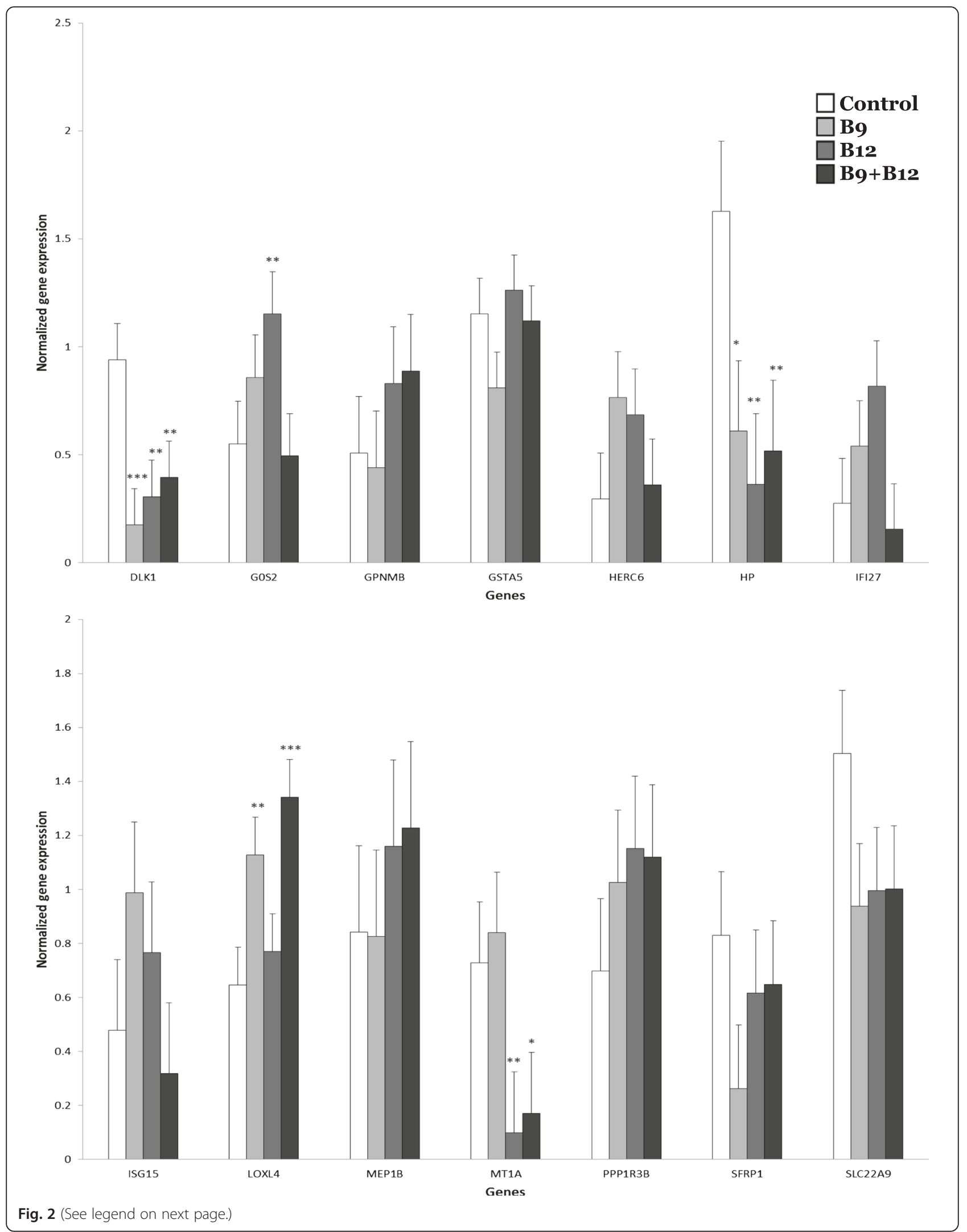


(See figure on previous page.)

Fig. 2 Expression of genes measured by quantitative $P C R$ in the liver of the dairy cows that received either no vitamin supplement: Control: no vitamin supplement; vitamin B9 supplement (B9); vitamin B12 supplement (B12) or a combined supplement of vitamins B9 and B12 (B9 + B12). Means different from the control treatment are indicated by *** when $P$ value $\leq 0.01$, ** when $P$ values were between 0.01 and 0.05 and * when there was a trend with $P$ values between 0.05 and 0.1

organism [18]. Notwithstanding, some genes in both tissues (liver and mammary gland) could not be assigned to any biological process or molecular function category by Panther classification system (Tables 1, 2, 3 and 4). It is also possible that there is no experimental data to support their biological annotation.

\section{Discussion}

Microarray analysis was used to investigate the effects of vitamin B9 and B12 supplements given alone or in combination during the peripartum early lactation period on liver and mammary gland tissues. The expression of only a limited number of genes was modulated by the vitamin treatments in both tissues, which suggests a subtle vitamin effect on the tissue metabolism that would have been better characterized using a larger population. Notwithstanding, the qPCR analyses show that, in liver, expression of keys genes, such as DLK1, LOXL4, GOS2, GSTA5, HP, MT1A, IFI27 and SFRP1 was modulated at different extents (significant effects for five genes and a strong trend for three genes) by the vitamin treatments. Delta-like 1 homolog (DLK1/Pref-1) is a surface marker of hematopoietic progenitor cells (HPCs) associated with less differentiated hepatocellular phenotypes [19] and it has been shown to act in vitro as an inhibitor of Notch signaling $[20,21]$ to promote liver regeneration [21]. Interestingly, $D L K 1$ is an imprinted gene which is involved in lipid metabolic reprogramming [22]. An increased concentration of this biomarker in blood serum is associated with hepatic cancer [23] whereas downregulation of DLK1 expression through an epigenetic mechanism contributes to attenuate liver disease [24]. Because vitamin B9 plays a major role in de novo formation of methyl groups and vitamin B12 is required for the remethylation cycle, we can speculate that DLK1 expression could also be repressed in the liver of the lactating cows through an epigenetic mechanism. Because $D L K 1$ suppresses glucose production and fatty acid synthesis and oxidation in hepatocytes [25], supplementation of both vitamins B9 and B12 might increase liver metabolism through a genomic imprinting mechanism which negatively impacts the $D L K 1$ pathway.

Lysyl oxidase-like member 4 (LOXL4), a matrixremodeling enzymes, is extracellularly secreted and significantly contributes to ECM deposition [26]. Activity of lysyl oxidase (LOX) and LOX like proteins are correlated to collagen and elastin deposition and, in adult mammals, are essential to tissue maintenance [27]. Recent studies have provided compelling evidence that GOS2 is abundantly expressed in metabolically active tissues such as liver, and acts as a molecular brake on triglyceride catabolism [28]. Triglyceride hydrolase activity of adipose triglyceride lipase can be selectively inhibited by GOS2 [28]. Hence, increasing the expression of GOS2 decreased lipolysis [29] which is supported by the reduction of plasma concentrations of non-esterified fatty acids in cows receiving vitamin B9 supplements, alone or combined with vitamin B12 in the present study. Although increased IFI27 expression was not significant, the pattern was highly similar to GOS2 thus suggesting a similar B9 supplement effect on the liver for this gene. Expression of the alpha-inducible protein 27 (IFI27) is up-regulated during inflammatory wound repair process [30] and expression of this gene also alters immune response and mitochondrial function [31]. Interestingly, DLK1 locus expression is also associated with a restriction of the mitochondrial metabolism [32]. These gene expression patterns support the hypothesis that both vitamins B9 and B12 improve the hepatic function which might reduce metabolic stress during the transition period and early lactation of dairy cows. This is further supported by the marked reduction of the HP and MT1A genes. The liver is the major site for the synthesis of acute phase proteins including haptoglobin $(H P)$ and metallothionein 1A (MT1A) [30]. During stress response, it is reported that physiological processes aimed on redistribution of energy utilization in specific organs stimulating mobilization of body reserves. In mammary gland, administration of the three vitamin treatments had a very limited effect on gene expression as described above. Interestingly, in the present study, whereas vitamin treatments had no effect on milk total solids yield and dry matter intake, vitamin B9 supplements, given alone or in combination with vitamin B12, decreased body condition score losses during the first weeks of lactation as well as plasma concentrations of non-esterified fatty acids and $\beta$-hydroxybutyrate [9] suggesting an improvement in energy balance for these cows.

In the present study, all the genes that have their expression affected by the vitamin treatments in the liver, are involved in tissue repair, resorption of inflammation and lipid metabolism although no mode of action can be clearly identified. During the first weeks of lactation, dairy cows are generally in negative energy balance because nutrient intake increases less rapidly than nutrient demand for initiation of lactation which leads to mobilization of body reserves. Cows are losing 


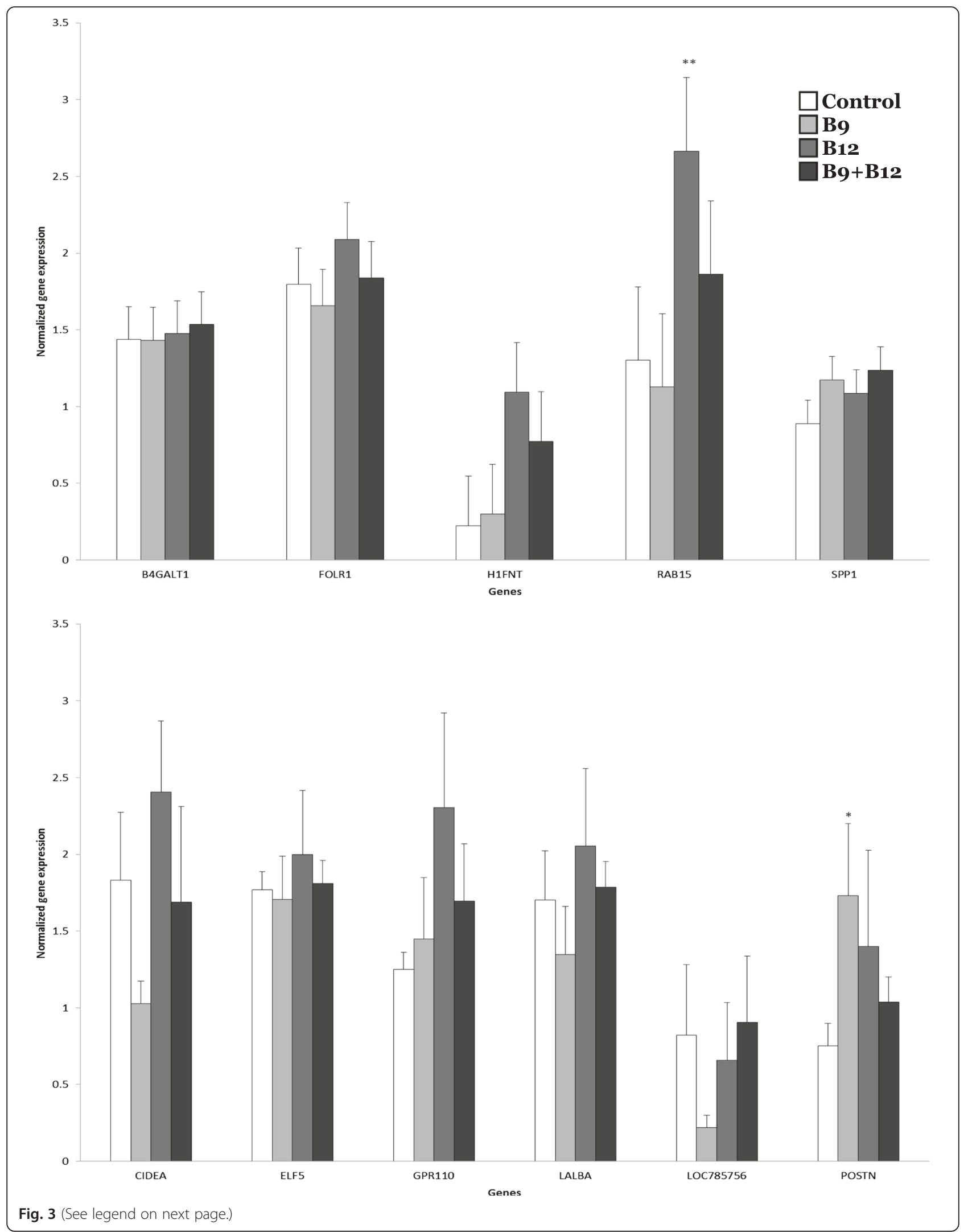


(See figure on previous page.)

Fig. 3 Expression of genes in mammary gland measured by quantitative PCR according to treatments. Control: no vitamin supplement; B9: vitamin B9 supplement; B12: vitamin B12 supplement; B9+B12: combined supplement of vitamins B9 and B12. Means different from the control treatment are indicated by ${ }^{* * *}$ when $P$ value $\leq 0.01,{ }^{* *}$ when $P$ values were between 0.01 and 0.05 and * when there was a trend with $P$ values between 0.05 and 0.1

body condition score and non-esterified fatty acids are released from adipose tissues and their plasma concentrations increased. During this period, dairy cows are also prone to liver steatosis because hepatic uptake of non-esterified fatty acids is greater than the amounts oxidized or secreted by the liver [33]. Accumulation of lipids in liver affects integrity and function of hepatic cells [33]; in response, liver parenchymal cells produce an acute-phase glycoprotein haptoglobulin [34]. Because a decrease in $D L K 1$ can improved fatty acid oxidation from hepatocytes [25], an improved $\beta$-oxidation of non-esterified fatty acids in liver could help to reduce ketone body formation and plasma concentrations of $\beta$-hydroxybutyrate. The improvement in energy balance observed in cows receiving supplementary vitamin B9, alone or combined with vitamin B12, likely reduced the liver burden caused by mobilization of body fat reserves which could explain the changes in hepatic gene expression described above. For instance, the increase of LOXL4 and GOS2 strongly support that these treatments protect body fat from catabolism. Prevention of liver damage or improved liver performance is not only important for maintaining liver function but also for general health of high-yielding dairy cows.

\section{Conclusion}

In the present study, a supplement of vitamin B9, given alone or in combination with vitamin B12, reduced mobilization of body fat reserves and hepatic lipid catabolism in early lactation. Changes in expression of genes described above support the hypothesis that hepatic tissue integrity in early lactation was improved by these vitamin supplements.

\section{Methods}

\section{Animals and treatments}

For the purpose of the present study, biopsies of hepatic and mammary tissues were taken from 24 multiparous Holstein cows from the dairy herd at the Agriculture and Agri-Food Canada Research Centre (Sherbrooke, Quebec, Canada) at the end of a larger study [9]. Care of cows followed the guidelines of the National Farm Animal Care Council (2009) [35]. Animals were kept in a tie-stall barn under 18:30 h of light per day (05:00 to 23:30 h) and milked twice daily (07:30 and 19:30 h). The experimental period began 3 weeks before the expected calving date and lasted until 9 weeks of lactation. The cows were fed ad libitum a close-up diet beginning
3 weeks before the expected date of calving until parturition and, then a lactation diet both formulated to meet or exceed the National Research Council (NRC) recommendations [36]. Long hay $(0.5 \mathrm{~kg})$ was given at $07: 30 \mathrm{~h}$ and total mixed ration was served once daily at 08:30 h. Cows had free access to water.

Cows were assigned to 6 blocks of 4 animals each according to their 305-d milk production during the previous lactation. Within each block, cows were randomly assigned to one of the following treatments: weekly intramuscular injections of $5 \mathrm{~mL}$ of either saline $0.9 \%$ $\mathrm{NaCl}$ (Control group), $320 \mathrm{mg}$ of pteroylmonoglutamic acid (MP Biomedicals, Solon, OH, USA; (Vitamin B9 group), $10 \mathrm{mg}$ of cyanocobalamin (5 $000 \mu \mathrm{g} / \mathrm{mL}$, Vetoquinol, Lavaltrie, Quebec, Canada; (Vitamin B12 group) or $320 \mathrm{mg}$ of pteroylmonoglutamic acid and $10 \mathrm{mg}$ of cyanocobalamin (B9 + B12 group). Thus, there were 6 animals per treatment group.

\section{Biological material collection and tissue handling}

Mammary gland and hepatic tissues were obtained from the lactating dairy cows, $64 \pm 3$ days after calving. Biopsies were performed under local anesthesia. The process of hepatic biopsies uses ultrasound guidance to minimize the hemorrhagic risks [4]. Both procedures were approved by the Institutional Committee on Animal Care of the Sherbrooke Research and Development Centre, Agriculture and Agri-Food Canada, Sherbrooke, QC, Canada according to the guidelines of the Canadian Coucil on Animal Care [37]. Tissues were immediately frozen into liquid nitrogen and stored at $-80{ }^{\circ} \mathrm{C}$ until use.

\section{Total RNA isolation and purification}

Total RNA was extracted from hepatic and mammary tissues by using a QIAzol Lysis Reagent (QIAGEN Inc., Toronto, ON, Canada) following the original manufacturer's protocol, with slight modifications. Briefly, frozen samples (100 mg of tissue) were homogenized in $2 \mathrm{~mL}$ of QIAzol Lysis Reagent on ice using a Tissue-Tearor. A volume of $600 \mu \mathrm{L}$ QIAzol Lysis Reagent was added to $400 \mu \mathrm{L}$ of homogenate; the mixture was vigorously vortexed and kept at room temperature for $5 \mathrm{~min}$ to promote dissociation of nucleoprotein complexes. A volume of $200 \mu \mathrm{L}$ of chloroform was added; the mixture was shaken and left at room temperature for $3 \mathrm{~min}$ followed by a centrifugation at $12000 \times \mathrm{g}$ for $15 \mathrm{~min}$ at $4{ }^{\circ} \mathrm{C}$ to remove lipids. After centrifugation, the aqueous fraction (upper layer) was taken and RNA was precipitated by 
Table 3 Panther gene list classification system for the genes differentially expressed in mammary gland tissue

\begin{tabular}{|c|c|c|c|c|c|}
\hline Treatment Gene symbol & Gene name & Treatment regulation effect & Molecular Function & Biological Process & Protein Class \\
\hline \multicolumn{6}{|l|}{ B9 } \\
\hline POSTN & Periostin & Up- & receptor binding & $\begin{array}{l}\text { cell communication } \\
\text { cell-matrix adhesion } \\
\text { visual perception } \\
\text { sensory perception } \\
\text { mesoderm development } \\
\text { skeletal system development } \\
\text { muscle organ development }\end{array}$ & $\begin{array}{l}\text { signaling molecule } \\
\text { cell adhesion molecule }\end{array}$ \\
\hline FUT5 & Alpha-(1,3)-Fucosyltransferase & Up- & $\begin{array}{l}\text { transferase activity, transferring } \\
\text { glycosyl groups }\end{array}$ & protein glycosylation & glycosyltransferase \\
\hline ATP6V1G3 & V-Type Proton Atpase Subunit G 3 & Up- & $\begin{array}{l}\text { hydrolase activity } \\
\text { cation transmembrane } \\
\text { transporter activity } \\
\text { proton-transporting ATP synthase } \\
\text { activity, rotational mechanism }\end{array}$ & $\begin{array}{l}\text { nucleobase-containing } \\
\text { compound } \\
\text { metabolic process } \\
\text { cation transport }\end{array}$ & $\begin{array}{l}\text { ATP synthase } \\
\text { hydrolase }\end{array}$ \\
\hline LOC785756 & androgen binding protein beta-like & Down- & Unassigned & Unassigned & Unassigned \\
\hline MGC126945 & uncharacterized protein MGC126945 & Down- & receptor activity & $\begin{array}{l}\text { B cell mediated immunity } \\
\text { antigen processing and } \\
\text { presentation } \\
\text { cellular defense response }\end{array}$ & $\begin{array}{l}\text { immunoglobulin receptor } \\
\text { superfamily } \\
\text { major histocompatibility } \\
\text { complex antigen }\end{array}$ \\
\hline CIDEA & cell death-inducing DFFA-like effector a & Down- & Unassigned & induction of apoptosis & Unassigned \\
\hline \multicolumn{6}{|l|}{ B12 } \\
\hline GPR110 & G-Protein Coupled Receptor 110-Related & Up- & G-protein coupled receptor activity & $\begin{array}{l}\text { spermatogenesis } \\
\text { immune response } \\
\text { synaptic transmission } \\
\text { neurotransmitter secretion } \\
\text { mesoderm development } \\
\text { heart development } \\
\text { response to stress } \\
\text { intracellular protein transport } \\
\text { synaptic vesicle exocytosis }\end{array}$ & $\begin{array}{l}\text { G-protein coupled receptor } \\
\text { antibacterial response protein }\end{array}$ \\
\hline IRX6 & iroquois homeobox 6 & Up- & $\begin{array}{l}\text { sequence-specific DNA binding } \\
\text { transcription factor activity } \\
\text { sequence-specific DNA binding } \\
\text { transcription factor activity }\end{array}$ & $\begin{array}{l}\text { transcription from RNA } \\
\text { polymerase II promoter } \\
\text { ectoderm development } \\
\text { nervous system development } \\
\text { regulation of transcription from } \\
\text { RNA polymerase II promoter }\end{array}$ & $\begin{array}{l}\text { homeobox transcription factor } \\
\text { nucleic acid binding }\end{array}$ \\
\hline RAB15 & Ras-related protein Rab-15 & Up- & Unassigned & Unassigned & Unassigned \\
\hline
\end{tabular}


Table 3 Panther gene list classification system for the genes differentially expressed in mammary gland tissue ${ }^{\text {a }}$ (Continued)

\begin{tabular}{|c|c|c|c|c|c|}
\hline \multicolumn{6}{|l|}{$\mathrm{B} 9+\mathrm{B} 12$} \\
\hline LOC509034 & $\begin{array}{l}\text { feline leukemia virus subgroup } \\
\mathrm{C} \text { receptor-related protein } 2 \text {-like }\end{array}$ & Down- & transmembrane & transporter activity transport & Transporter \\
\hline IDO1 & indoleamine 2,3-dioxygenase 1 & Down- & Unassigned & Unassigned & Unassigned \\
\hline SECTM1 & SECTM1 protein & Down- & Unassigned & Unassigned & Unassigned \\
\hline
\end{tabular}

Differentially expressed genes in mammary tissue were assigned to gene ontology pathways using the Panther tool. Some genes were not found in Panther genes list. Furthermore, among the genes ID found by the

PANTHER system, some were not classified to a category. Only 3 genes ontology categories are presented: Molecular Function, Biological Process and Protein Class
${ }^{a}$ Classification with the Panther gene list classification system of the genes differentially expressed in mammary tissue following supplementation with vitamin B9 (B9), vitamin B12 (B12) or both (B9 + B12) as

compared to no vitamin treatment (Control) 
Table 4 Identification of the major biological processes of the genes differentially expressed in mammary gland tissue

\begin{tabular}{|c|c|c|c|}
\hline \multicolumn{2}{|l|}{ Biological process } & \multicolumn{2}{|l|}{ Genes } \\
\hline Level 1 & Level 2/3 & Symbol & Fold change \\
\hline apoptotic process & induction of apoptosis & CIDEA & -1.9 \\
\hline biological adhesion & cell adhesion & POSTN & 1.1 \\
\hline biological regulation & regulation of biological process & IRX6 & 1.7 \\
\hline cellular process & cell communication & $\begin{array}{l}\text { POSTN } \\
\text { GPR110 }\end{array}$ & $\begin{array}{l}1.1 \\
1.3\end{array}$ \\
\hline \multirow[t]{4}{*}{ developmental process } & death & CIDEA & -1.9 \\
\hline & ectoderm development & IRX6 & 1.7 \\
\hline & mesoderm development & $\begin{array}{l}\text { POSTN } \\
\text { GPR110 }\end{array}$ & $\begin{array}{l}1.1 \\
1.3\end{array}$ \\
\hline & system development & $\begin{array}{l}\text { POSTN } \\
\text { GPR110 } \\
\text { IRX6 }\end{array}$ & $\begin{array}{l}1.1 \\
1.3 \\
1.7\end{array}$ \\
\hline \multirow[t]{2}{*}{ immune system process } & antigen processing and presentation & MGC126945 & -1.5 \\
\hline & immune response & $\begin{array}{l}\text { MGC126945 } \\
\text { GPR110 }\end{array}$ & $\begin{array}{l}-1.9 \\
1.3\end{array}$ \\
\hline localization & transport & $\begin{array}{l}\text { ATP6V1G3 } \\
\text { LOC509034 } \\
\text { GPR110 }\end{array}$ & $\begin{array}{l}-0.9 \\
-0.6 \\
1.3\end{array}$ \\
\hline \multirow[t]{2}{*}{ metabolic process } & nucleobase-containing compound metabolic process & $\begin{array}{l}\text { ATP6VIG3 } \\
\text { IRX6 }\end{array}$ & $\begin{array}{l}-0.9 \\
1.7\end{array}$ \\
\hline & protein metabolic process & FUT5 & 3.6 \\
\hline multicellular organismal process & single-multicellular organism process & $\begin{array}{l}\text { POSTN } \\
\text { GPR110 }\end{array}$ & $\begin{array}{l}1.1 \\
1.3\end{array}$ \\
\hline reproduction & gamete generation & GPR110 & 1.3 \\
\hline \multirow[t]{3}{*}{ response to stimulus } & cellular defense response & MGC126945 & -1.9 \\
\hline & immune response & $\begin{array}{l}\text { MGC126945 } \\
\text { GPR110 }\end{array}$ & $\begin{array}{l}-1.9 \\
1.3\end{array}$ \\
\hline & response to stress & GPR110 & 1.3 \\
\hline Not found & & $\begin{array}{l}\text { LOC751574 } \\
\text { VAV1 } \\
\text { LOC614268 } \\
\text { SAA2 } \\
\text { C1OH140rf53 } \\
\text { H1FNT }\end{array}$ & $\begin{array}{l}-1.3 \\
-1.2 \\
-0.9 \\
-0.9 \\
1.4 \\
4.9\end{array}$ \\
\hline Unassigned & & $\begin{array}{l}\text { LOC785756 } \\
\text { IDO1 } \\
\text { SECTM1 } \\
\text { RAB15 }\end{array}$ & $\begin{array}{l}-2.1 \\
-1.2 \\
-0.9 \\
2.0\end{array}$ \\
\hline
\end{tabular}

All genes modulated in the mammary tissue by the vitamins treatment, including those that were not found or classified by the Panther system are listed. The Fold Change, as using FlexArray microarray analysis, varies from -1.9 to 4.9 and only significantly (FDR $\leq 0.05$ ) expressed genes (compared to control) are shown adentification of the major biological processes of the genes differentially expressed in mammary tissue following supplementation with vitamin B9 (B9), vitamin $\mathrm{B} 12$ (B12) or both vitamins (B9 + B12) as compared to no vitamin treatment (Control)

adding an equal volume of $70 \%$ ethanol. RNA was purified according to manufacturer's procedure using RNeasy Mini Kit (QIAGEN Inc., Toronto, ON, Canada), including oncolumn DNase digestion. The purity, concentration, and integrity of total RNA intended for qPCR were assessed. Purity of the RNA was evaluated by absorbance (A) readings (ratio of A260/A230 and A260/A280) using a NanoDrop ND-1000 spectrophotometer (Thermo Fisher Scientific, Waltham, MA, US). NanoDrop ND-1000 spectrophotometer was also used to measure the concentration.
All RNA samples passed the quality control. The RNA Integrity Number calculated by the Bioanalyzer software at McGill University and Génome Québec Innovation Center (Montreal, Quebec, Canada) ranged from 7.3 to 8.7.

\section{Microarray}

McGill University and Génome Québec Innovation Center (Montreal, Quebec, Canada) performed the microarray analysis. Cyanine 3-labeled CTP complementary RNA (cRNA) was produced with 50 ng of total RNA using 
the Low Input Quick Amp Labeling Kit, according to manufacturer's instructions (Agilent Technologies, Inc). The quality of cRNA was evaluated by capillary electrophoresis on 2100 Electrophoresis Bioanalyzer instrument (Agilent technologies, Santa Clara, CA, USA). A total of 15525 genes were analyzed via expression levels of 42789 probes using the Agilent Bovine Genome Oligo Microarrays $4 \times 44 \mathrm{~K}(\mathrm{G} 2519 \mathrm{~F}-023647)$ (Agilent technologies, Santa Clara, CA, USA). Labeling, hybridization, and raw data extraction were performed by McGill University and Génome Québec Innovation Center (Montreal, Quebec, Canada) according to the manufacturer's instructions, as previously described [38]. Hybridizations were performed by batch with samples randomly distributed. The hybridizations of microarrays were compared through a correlation matrix that enables the quick identification of poor and divergent replication (data not shown). Once the slides are scanned, the respective ".tif" image was examined using the Agilent Feature Extraction (FE) software. Scan image information is displayed in the Scan Image Properties for images that were generated using the Agilent Scanner. Then data are extracted with the FE software. A quality control (QC) report is generated for each sample. The FE version 10.7.3.1 with GE1_107_Sep09 protocol and grid associated with the selected type of chip 023647_D_F_20110614 were used. All microarray datasets passed all the quality criteria and were then downloaded into the FlexArray microarray analysis software (http:// gqinnovationcenter.com/documents/technicalNotes/technicalNotes_GQ06.pdf). Array data have been submitted to the public databases and assigned Gene Expression Omnibus (GEO) accession number is GSE77421.

FlexArray, a Bioconductor R based software, was developed by Génome Québec to provide researchers with a user-friendly interface for the analysis of microarray experiments. Raw microarray expression intensities were corrected for background using normexp, according to Ritchie et al. [39]. Between-array normalization was performed so that the background corrected intensities have similar distributions across the arrays. Comparison of the vitamin treatments with the control tissue was performed by Cyber-T, a version of the $t$-test that uses a Bayesian estimate of the within treatment variance $[40,41]$. Up- or downregulated genes lists were analyzed on Protein ANalysis THrough Evolutionary Relationships (Panther) classification system [42].

\section{Quantitative real time-PCR}

Quantifications by real-time PCR (qPCR) following reverse transcription were performed as previously described [43] with minor modifications. The reverse transcription PCR reactions were performed with the SuperScript II reverse transcriptase (Life Technologies Inc., Burlington ON, Canada) according to the manufacturer's protocol and using $500 \mathrm{ng}$ of total RNA extracted from each of the 24 animals. An equivalent quantity of cDNA is synthesized in a final reaction volume of $20 \mu \mathrm{L}$, giving a concentration of $25 \mathrm{ng} / \mu \mathrm{l}$ of cDNA. A pool of cDNA intended to estimate the efficiencies primers, was made using the cDNA of each animal. Primers were designed for each gene using the Primer Express 3 software package (Applied Biosystems, Life Technologies Corporation, Burlington, ON, Canada) using the reference sequence from the RefSeq database of the National Center for Biotechnology Information depository. Primers for a total of 34 genes for both tissues were designed. Optimizations of primers were performed for each gene by testing different concentrations of both forward and reverse primers, each ranging from 50 to $900 \mathrm{nM}$. Estimations of primer efficiencies were analyzed using the standard curves made from a serial of seven dilutions $(1 / 7.5,1 / 15,1 / 30,1 / 60,1 /$ $120,1 / 240,1 / 480)$ of the pool of the cDNA samples ( $25 \mathrm{ng} / \mu \mathrm{l}$ of cDNA). As $3 \mu \mathrm{l}$ of each dilution were used in a final reaction volume of $10 \mu \mathrm{l}$ for qPCR, the concentrations used per dilution were: $1,0.5,0.25,0.125$, $0.0625,0.03125$ and $0.015625(\mathrm{ng} / \mu \mathrm{l})$. Additional file 1 provides experimental information and PCR amplification efficiency for all genes. The qPCR reactions $(10 \mu \mathrm{L}$, final volume) were performed on 96 well plates using Fast SYBR Green PCR Master Mix (Applied Biosystems) in a 7500 Fast Real Time-PCR System (Life Technologies, Burlington, ON, Canada) as the manufacturer's instructions. The PCR thermal cycling conditions comprised an initial $20 \mathrm{~s}$ denaturation step at $95{ }^{\circ} \mathrm{C}$ followed by 40 cycles at $95{ }^{\circ} \mathrm{C}$ for $3 \mathrm{~s}$ followed by an annealing/elongation period at $60{ }^{\circ} \mathrm{C}$ for $30 \mathrm{~s}$. A dissociation step was included for all amplifications to confirm the presence of single discrete PCR products of the expected size. Twenty-five genes (14 from hepatic tissue data and 11 from mammary gland tissue data) were subject to $\mathrm{qPCR}$ validation because they were found differentially expressed by microarray as expressed by $\log 2$ of their fold change. In addition, in the mammary gland, four genes (FOLR1, ELF5, B4GALT1 and $L A L B A$ ) were chosen because of their implication in the metabolic pathway involving vitamins B9 and B12. The expression of 5 putative reference genes, namely actin beta $(A C T B)$, ubiquitously-expressed transcript (UXT), peptidylprolyl isomerase A (PPIA), glyceraldehyde3-phosphate dehydrogenase (GAPDH), tyrosine 3-mono oxygenase/tryptophan 5-monooxygenase activation protein, zeta polypeptide (YWHAZ) was determined for all samples as recommended [44-46]. All the 24 animals were used to perform the qPCR analysis of 34 genes for both tissues. Once the more stable genes were selected, the normalization factor was calculated using a geometrical average as recommended [45]. The combination of $A C T B$ and PPIA was appropriate to normalize 
the data from hepatic tissue. The appropriated combination was $U X T$ and PPIA to normalize the data from mammary gland.

\section{Data analysis and statistics}

Using FlexArray microarray analysis, a significant result at a $P$ value $<0.05$ after false discovery rate correction with a minimum of \pm two-fold change in gene expression for the respective treatment group compared to control tissues was considered biologically interesting. Gene category overrepresentation analysis consists in grouping genes into categories by some common biological property and then tested to find categories that are over represented amongst the differentially expressed genes. Gene ontology describes and categorizes gene products in three non-overlapping domains of molecular biology [47]. Panther (http:// pantherdb.org) is a visualisation browser of GO [48], using version 10 which included other organisms. Panther ranks proteins (and their genes) according to Family (and subfamily), Molecular function, Biological process and Pathway. The process of classification is extensively explained by $\mathrm{Mi}$ and colleagues [42]. Only significant differentially expressed genes were analysed by qPCR. Data from qPCR were analyzed using SAS Institute procedures (2008). Means were assumed to be different at $P \leq 0.05$ and tended to differ at $0.05<P \geq 0.1$. Normfinder indicated the interested combination of reference genes to normalize qPCR data.

\section{Additional file}

Additional file 1: Oligonucleotide primer sequences for quantitative PCR. (DOCX $32 \mathrm{~kb}$ )

\section{Abbreviations}

ECM, extracellular matrix components; GO, gene ontology; HPCs, hepatic progenitor cells; Panther, protein analysis through evolutionary relationships; qPCR, quantitative polymerase chain reaction.

\begin{abstract}
Acknowledgements
The authors would like to thank Véronique Roy for her assistance with tissue sampling, Catherine Thibault for coordinating the extraction step and the design of the $\mathrm{PPCR}$ assay, Gloria-Gabrielle Ortega-Delgado providing technical assistance for performing $\mathrm{QPCR}$ assays and Steve Méthot for statistical analysis.
\end{abstract}

\section{Funding}

The present project was publicly supported research within Agriculture and Agroalimentaire Canada (ACC) using hepatic and mammary tissue samples collected during a project funded by Novalait - Agriculture et Agroalimentaire Canada - Fonds de recherche du Québec Nature et Technologies - Ministère de l'Agriculture, des Pêcheries et de I'Alimentation du Québec, Québec, Québec, Canada.

\section{Availability of data and materials}

All microarray datasets were then downloaded into the FlexArray microarray analysis software (http://gqinnovationcenter.com/documents/ technicalNotes/technicalNotes_GQ06.pdf). Array raw data have been submitted to the public databases. The following link (http:// www.ncbi.nlm.nih.gov/geo/query/acc.cgi?acc=GSE77421) provides access to all data. The assigned Gene Expression Omnibus (GEO) accession number is GSE77421.

\section{Authors' contributions}

$\mathrm{BO}, \mathrm{NB}, \mathrm{MD}$ and $\mathrm{CLG}$ contributed in the design of the study, interpretation of the results, writing of the manuscript, revision of its content and approval of the final version submitted for publication; $M D$ realized the animal phase of the project; BO realized laboratory analyses; N. B. performed microarray analysis and supervised RT-PCR analyses; CLG was the principal investigator of the project. All authors have read and approved the final manuscript.

\section{Competing interests}

The authors declare that they have no competing interests.

\section{Consent for publication}

Not applicable.

\section{Ethics approval and consent to participate}

Care of cows followed the guidelines of the National Farm Animal Care Council. The protocol was approved by the Institutional Committee on Animal Care of the Sherbrooke Research and Development Centre, Agriculture and Agri-Food Canada, Sherbrooke, QC, Canada according to the guidelines of the Canadian Council on Animal Care. Consent to participate is not applicable because the study did not involve human subjects, human material or human data.

\section{Author details}

${ }^{1}$ Sherbrooke Research and Development Centre, Agriculture and Agri-Food Canada, Sherbrooke, QC J1M 0C8, Canada. ${ }^{2}$ Current address: Valacta, Ste-Anne-de-Bellevue, Québec H9X 3R4, Canada.

Received: 20 January 2016 Accepted: 30 June 2016 Published online: 15 August 2016

\section{References}

1. Lardinois CC, Mills RC, Elyehjem CA, Hart EB. Rumen synthesis of the vitamin B complex as influenced by ration composition. J Dairy Sci. 1944;27(7):579-83.

2. Girard $\mathrm{CL}$, Matte JJ. Effects of intramuscular injections of vitamin B12 on lactation performance of dairy cows fed dietary supplements of folic acid and rumen-protected methionine. J Dairy Sci. 2005:88(2):671-6.

3. Preynat A, Lapierre H, Thivierge MC, Palin MF, Matte JJ, Desrochers A, et al. Effects of supplements of folic acid, vitamin B12, and rumen-protected methionine on whole body metabolism of methionine and glucose in lactating dairy cows. J Dairy Sci. 2009;92(2):677-89.

4. Graulet B, Matte JJ, Desrochers A, Doepel L, Palin MF, Girard CL. Effects of dietary supplements of folic acid and vitamin B12 on metabolism of dairy cows in early lactation. J Dairy Sci. 2007;90(7):3442-55.

5. Scott JM. Folate and vitamin B12. Proc Nutr Soc. 1999:58(2):441-8.

6. Girard CL, Matte JJ, Tremblay GF. Gestation and lactation of dairy cows: a role for folic acid? J Dairy Sci. 1995;78(2):404-11.

7. Girard CL, Matte JJ. Dietary supplements of folic acid during lactation: effects on the performance of dairy cows. J Dairy Sci. 1998;81(5):1412-9.

8. Menzies KK, Lefevre C, Macmillan KL, Nicholas KR. Insulin regulates milk protein synthesis at multiple levels in the bovine mammary gland. Funct Integr Genomics. 2009:9(2):197-217.

9. Duplessis M. Impact d'un supplément combine d'acide folique et de vitamine B12 en période prépartum et en début de lactation chez la vache laitière. Université Laval 2014. PhD Thesis. Univ. Laval, Quebec, QC, Canada, p. 301.

10. McEwen M, Reynolds K. Noninvasive detection of bilirubin using pulsatile absorption. Australas Phys Eng Sci Med. 2006;29(1):78-83.

11. Larsen M, Kristensen NB. Precursors for liver gluconeogenesis in periparturient dairy cows. Animal. 2013;7(10):1640-50.

12. Amaral DM, Veenhuizen JJ, Drackley JK, Cooley MH, McGilliard AD, Young JW. Metabolism of propionate, glucose, and carbon dioxide as affected by exogenous glucose in dairy cows at energy equilibrium. J Dairy Sci. 1990:73(5):1244-54.

13. Danfaer A, Tetens $V$, Agergaard N. Review and an experimental study on the physiological and quantitative aspects of gluconeogenesis in lactating ruminants. Comp Biochem Physiol B Biochem Mol Biol. 1995;111(2):201-10.

14. Nafikov RA, Beitz DC. Carbohydrate and lipid metabolism in farm animals. J Nutr. 2007;137(3):702-5.

15. Grummer RR. Impact of changes in organic nutrient metabolism on feeding the transition dairy cow. J Anim Sci. 1995;73(9):2820-33. 
16. McCarthy SD, Waters SM, Kenny DA, Diskin MG, Fitzpatrick R, Patton J, et al. Negative energy balance and hepatic gene expression patterns in high-yielding dairy cows during the early postpartum period: a global approach. Physiol Genomics. 2010;42A(3):188-99.

17. Connor EE, Siferd S, Elsasser TH, Evock-Clover CM, Van Tassell CP, Sonstegard $T S$, et al. Effects of increased milking frequency on gene expression in the bovine mammary gland. BMC Genomics. 2008;9:362.

18. Mi H, Muruganujan A, Casagrande JT, Thomas PD. Large-scale gene function analysis with the PANTHER classification system. Nat Protoc 2013;8(8):1551-66.

19. Jelnes P, Santoni-Rugiu E, Rasmussen M, Friis SL, Nielsen JH, Tygstrup N, et al. Remarkable heterogeneity displayed by oval cells in rat and mouse models of stem cell-mediated liver regeneration. Hepatology. 2007;45(6):1462-70.

20. Falix FA, Aronson DC, Lamers WH, Gaemers IC. Possible roles of DLK1 in the Notch pathway during development and disease. Biochim Biophys Acta. 2012;1822(6):988-95.

21. Zhu NL, Asahina K, Wang J, Ueno A, Lazaro R, Miyaoka Y, et al. Hepatic stellate cell-derived delta-like homolog 1 (DLK1) protein in liver regeneration. J Biol Chem. 2012;287(13):10355-67.

22. Tsukamoto $H$. Metabolic reprogramming and cell fate regulation in alcoholic liver disease. Pancreatology. 2015;15(4 Suppl):S61-65.

23. Li H, Cui ML, Chen TY, Xie HY, Cui Y, Tu H, et al. Serum DLK1 is a potential prognostic biomarker in patients with hepatocellular carcinoma. Tumour Biol. 2015;36(11):8399-404

24. Pan RL, Xiang LX, Wang $P$, Liu $X Y$, Nie L, Huang $W$, et al. Low-molecularweight fibroblast growth factor 2 attenuates hepatic fibrosis by epigenetic down-regulation of Delta-like1. Hepatology. 2015;61(5):1708-20.

25. Lee $\mathrm{YH}$, Yun MR, Kim HM, Jeon BH, Park BC, Lee BW, et al. Exogenous administration of DLK1 ameliorates hepatic steatosis and regulates gluconeogenesis via activation of AMPK. Int J Obes (Lond). 2016;40(2):356-65.

26. Busnadiego O, Gonzalez-Santamaria J, Lagares D, Guinea-Viniegra J, PicholThievend C, Muller L, et al. LOXL4 is induced by transforming growth factor beta1 through Smad and JunB/Fra2 and contributes to vascular matrix remodeling. Mol Cell Biol. 2013;33(12):2388-401.

27. Hayashi K, Fong KS, Mercier F, Boyd CD, Csiszar K, Hayashi M. Comparative immunocytochemical localization of lysyl oxidase (LOX) and the lysyl oxidaselike (LOXL) proteins: changes in the expression of LOXL during development and growth of mouse tissues. J Mol Histol. 2004:35(8-9):845-55.

28. Yang X, Zhang X, Heckmann BL, Lu X, Liu J. Relative contribution of adipose triglyceride lipase and hormone-sensitive lipase to tumor necrosis factor-alpha (TNF-alpha)-induced lipolysis in adipocytes. J Biol Chem. 2010;286(47):40477-85.

29. Yang $X$, Lu X, Lombes $M$, Rha GB, Chi Yl, Guerin TM, et al. The $G(0) / G(1)$ switch gene 2 regulates adipose lipolysis through association with adipose triglyceride lipase. Cell Metab. 2011;11(3):194-205.

30. Gessner DK, Schlegel G, Keller J, Schwarz FJ, Ringseis R, Eder K. Expression of target genes of nuclear factor E2-related factor 2 in the liver of dairy cows in the transition period and at different stages of lactation. J Dairy Sci. 2013;96(2):1038-43.

31. Hsiao CP, Araneta M, Wang XM, Saligan LN. The association of IFI27 expression and fatigue intensification during localized radiation therapy: implication of a para-inflammatory bystander response. Int J Mol Sci. 2013;14(8):16943-57.

32. Qian P, He XC, Paulson A, Li Z, Tao F, Perry JM, et al. The DIk1-Gtl2 Locus Preserves LT-HSC Function by Inhibiting the PI3K-mTOR Pathway to Restrict Mitochondrial Metabolism. Cell Stem Cell. 2016;18(2):214-28.

33. Bobe G, Young JW, Beitz DC. Invited review: pathology, etiology, prevention, and treatment of fatty liver in dairy cows. J Dairy Sci. 2004;87(10):3105-24.

34. Katoh N. Relevance of apolipoproteins in the development of fatty liver and fatty liver-related peripartum diseases in dairy cows. J Vet Med Sci. 2002;64(4):293-307.

35. NFACC. Code of practice for the care and handling of dairy cattle. Ottawa, Ontario, Canada: Dairy Farmers of Canada and National Farm Animal care Council (DFCNFCC); 2009

36. NRC. Nutrient Requirements of Dairy Cattle. Seventh Revised Edition, 2001. Washington, DC: The National Academies Press; 2001. p. 2001.

37. CCAC. CCAC quidelines on: laboratory animal facilities - characteristics, design, and development. 2003.

38. Rudkowska I, Paradis AM, Thifault E, Julien P, Tchernof A, Couture P, et al. Transcriptomic and metabolomic signatures of an $n-3$ polyunsaturated fatty acids supplementation in a normolipidemic/normocholesterolemic Caucasian population. J Nutr Biochem. 2013;24(1):54-61.
39. Ritchie ME, Silver J, Oshlack A, Holmes M, Diyagama D, Holloway A, et al. A comparison of background correction methods for two-colour microarrays. Bioinformatics. 2007;23(20):2700-7.

40. Baldi $P$, Long $A D$. A Bayesian framework for the analysis of microarray expression data: regularized $t$-test and statistical inferences of gene changes. Bioinformatics. 2001;17(6):509-19.

41. Kayala MA, Baldi P. Cyber-T web server: differential analysis of highthroughput data. Nucleic Acids Res. 2012;40(Web Server issue):W553-559.

42. Mi H, Poudel S, Muruganujan A, Casagrande JT, Thomas PD. PANTHER version 10: expanded protein families and functions, and analysis tools. Nucleic Acids Res. 2016:44(D1):D336-342

43. Levesque-Sergerie JP, Duquette M, Thibault C, Delbecchi L, Bissonnette N. Detection limits of several commercial reverse transcriptase enzymes: impact on the low- and high-abundance transcript levels assessed by quantitative RT-PCR. BMC Mol Biol. 2007:8:93.

44. Lisowski P, Pierzchala M, Goscik J, Pareek CS, Zwierzchowski L. Evaluation of reference genes for studies of gene expression in the bovine liver, kidney, pituitary, and thyroid. J Appl Genet. 2008;49(4):367-72.

45. Bionaz M, Loor JJ. Identification of reference genes for quantitative real-time PCR in the bovine mammary gland during the lactation cycle. Physiol Genomics. 2007;29(3):312-9.

46. Kadegowda AK, Bionaz M, Thering B, Piperova LS, Erdman RA, Loor J. Identification of internal control genes for quantitative polymerase chain reaction in mammary tissue of lactating cows receiving lipid supplements. J Dairy Sci. 2009;92(5):2007-19.

47. Harris MA, Clark J, Ireland A, Lomax J, Ashburner M, Foulger R, et al. The Gene Ontology (GO) database and informatics resource. Nucleic Acids Res. 2004;32(Database issue):D258-261.

48. Thomas PD, Campbell MJ, Kejariwal A, Mi H, Karlak B, Daverman R, et al. PANTHER: a library of protein families and subfamilies indexed by function. Genome Res. 2003:13(9):2129-41.

\section{Submit your next manuscript to BioMed Central and we will help you at every step:}

- We accept pre-submission inquiries

- Our selector tool helps you to find the most relevant journal

- We provide round the clock customer support

- Convenient online submission

- Thorough peer review

- Inclusion in PubMed and all major indexing services

- Maximum visibility for your research

Submit your manuscript at www.biomedcentral.com/submit
) Biomed Central 